\title{
Release of macromolecular organic complexes by heterotrophic marine flagellates
}

\author{
Toshi Nagata*, David L. Kirchman \\ College of Marine Studies, University of Delaware, Lewes, Delaware 19958, USA
}

\begin{abstract}
We examined whether or not the heterotrophic marine flagellate Paraphysomonas imperforata releases macromolecular dissolved organic matter (DOM). ${ }^{3} \mathrm{H}$-bacterial prey (Vibrio spp.) were added to flagellate cultures and the accumulation of ${ }^{3} \mathrm{H}$-DOM was measured. Flagellates released a large amount of macromolecular DOM (6 to $57 \%$ of ${ }^{3} \mathrm{H}$-DOM) that was rich in lipids (lipid . macromolecular ratio $=0.20: 0.92$ ). One component of the macromolecular DOM was a digestive enzyme (acid phosphatase) of the flagellate. The flagellate acid phosphatase was not degraded by proteases, but it was susceptible to proteases after treatment with polymyxin B, which destroys bacterial membranes. These data suggest that bacterial membranes protected the released acid phosphatase from proteolytic attack. Ultracentrifugation showed that the sedimentation coefficient of the phosphatase was 15 to $42 \mathrm{~S}$. consistent with the hypothesis that the phosphatase is part of a macromolecular complex. We hypothesize that flagellates release their own digestive enzymes and incompletely digested membranes and probably other cellular components from bacterial prey and that these compounds form liposomelike organic complexes. These complexes may be important for understanding the chemical nature and turnover of DOM in the oceans.
\end{abstract}

\section{INTRODUCTION}

Dissolved organic matter (DOM) represents a major fraction (>95\%) of total organic matter in the ocean and has important short- and long-term implications for plankton trophic interactions and oceanic biogeochemistry (Jackson \& Williams 1985, Toggweiler 1989, Kirchman et al. 1991). Previous work has identified many DOM compounds in seawater, including amino acids, nucleic acids, carbohydrates and lipids. However, much of the DOM has yet to be characterized (Williams \& Druffel 1988).

DOM is operationally defined as the fraction of organic material that passes through filters, usually glass fiber filters with nominal retention of $0.7 \mu \mathrm{m}$. With this definition, DOM includes various forms of macromolecules, some of which may actually be colloidal particles (0.001 to $1 \mu \mathrm{m}$ ) (Sharp 1973). Even microorganisms such as viruses, bacteria and small eucaryotes could be included in the 'DOM' fraction, although contributions of living particles to total colloids are

\footnotetext{
- Present address: Water Research Institute, Nagoya University, Chikusa-ku, Nagoya 464-01, Japan
}

reported to be low (Koike et al. 1990, Wells \& Goldberg 1991).

Macromolecular DOM accounts for 10 to $20 \%$ of total DOM (Sharp 1973, Ogura 1974) and it is potentially important in oceanic material cycling. Recent studies with particle counting (Koike et al. 1990, Longhurst et al. 1992) and electron microscopy (Wells \& Goldberg 1991) have revealed high abundance $\left(10^{7}\right.$ to $10^{9}$ particles $\mathrm{ml}^{-1}$ ) in surface waters and a complex vertical distribution of colloidal particles in the oceans. These results renewed interest in the ecological and biogeochemical importance of macromolecular DOM.

Little is known about the origin and chemical nature of macromolecular DOM in seawater. Koike et al. (1990) found that the abundance of colloidal particles (size: 0.36 to $1 \mu \mathrm{m}$ in diameter measured by particle counting) in seawater increased with the increase of heterotrophic flagellates grazing on bacteria. Based on this result, they suggested that heterotrophic flagellates produce submicron colloidal particles, but the actual mechanism is unclear. Nagata \& Kirchman (1991) found that heterotrophic marine flagellates grazing on bacteria release a large amount of dissolved free and combined amino acids during exponential growth. Based on the relation between ingestion rates and 
release rates of amino acids and ammonium and on theoretical considerations of digestion processes (Jumars et al. 1989), Nagata \& Kirchman hypothesized that flagellates release material from food vacuoles, which could include macromolecular DOM, during egestion. Previous studies with electron microscopy suggested that flagellates release undigested prey particles from exocytosis (e.g. Cole \& Wynne 1974). However, chemical characterization of released materials has yet to be done.

Here we examined the release of macromolecular DOM by bacterivorous marine flagellates. Results from these experiments suggest that flagellates release macromolecular organic complexes that contain lipids from prey bacteria and digestive enzymes from the flagellates. These organic complexes may be important in material cycling in the oceans.

\section{MATERIALS AND METHODS}

Heterotrophic flagellates Paraphysomonas imperforata were isolated and maintained as described previously (Nagata \& Kirchman 1991). For measurements of the release of ${ }^{3} \mathrm{H}$-compounds and acid phosphatase (see below), P. imperforata were grown on Vibrio splendidus as bacterial prey (Nagata \& Kirchman 1991).

To radiolabel the bacteria, an inoculum of bacteria (Vibrio splendidus, V. damsela, V. gazogenes, V. natriegens, $V$. proteolyticus) cultured on LM broth (Triptone, $10 \mathrm{~g}$; yeast extract, $5 \mathrm{~g}$; $\mathrm{NaCl}, 20 \mathrm{~g}$; and Milli $\mathrm{Q}$ water, 1 l) was added to a glucose medium which contained ${ }^{3} \mathrm{H}$-glucose $\left(100 \mu \mathrm{Ci} \mathrm{ml}{ }^{-1}\right)$. The medium consists of the basal salt solution (BSS: $\mathrm{NaCl}, 24 \mathrm{~g}_{i} \mathrm{MgSO}_{4}$ $6 \mathrm{H}_{2} \mathrm{O}, 6 \mathrm{~g}_{i} \mathrm{KCl}, 0.7 \mathrm{~g}_{i} \mathrm{MgCl}_{2} \cdot 6 \mathrm{H}_{2} \mathrm{O}, 5.3 \mathrm{~g}$, in $1 \mathrm{l}$ of Milli$Q$ water) enriched with vitamins and trace metals $[0.5$ $\mathrm{ml}$ of IMR vitamin/trace metal mixture (Eppley et al. $1967)$ per $1 \mathrm{l}$ of $\mathrm{BSS}$ ], glucose $(10 \mathrm{mM})$, phosphate (10 $\mathrm{mM})$, and $\left(\mathrm{NH}_{4}\right)_{2} \mathrm{SO}_{4}(5 \mathrm{mM})$. Since glucose was the sole carbon source for the bacteria, cell components of the bacteria were labeled uniformly. After incubation $\left(8 \mathrm{~h}, 30^{\circ} \mathrm{C}\right.$ ), bacteria were washed ( 4 times) and harvested $(8000 \times g, 10 \mathrm{~min})$ with artificial seawater (Nagata \& Kirchman 1991). We added the ${ }^{3} \mathrm{H}$-labeled bacteria to the culture of Paraphysomonas imperforata during the exponential (unlabeled bacterial abundance: $1 \times 10^{8}$ cells $\mathrm{ml}^{-1}$ ) or stationary growth phase (unlabeled bacteria: $5 \times 10^{5}$ cells $\mathrm{ml}^{-1}$ ) of the flagellate. The final abundance of ${ }^{3} \mathrm{H}$-bacteria was 3 to $6 \%$ and 97 to $180 \%$ of unlabeled prey abundance in the exponential and stationary cultures of flagellates, respectively. A bacteria-alone control was prepared by adding radiolabeled bacteria to the $0.8 \mu \mathrm{m}$ filtrate of the flagellate culture; $>95 \%$ of the flagellates were eliminated by this filtration. Immediately after addition of ${ }^{3} \mathrm{H}$ labeled bacteria (time zero) and after the incubation ( 6 h) at $22^{\circ} \mathrm{C}$ under the room light, $2 \mathrm{ml}$ subsamples were filtered through $0.2 \mu \mathrm{m}$ Acrodiscs with a syringe and the cell-free filtrate was collected. Cell breakage can be avoided with this filtration technique (Nagata \& Kirchman 1990).

We also measured the ${ }^{3} \mathrm{H}$-activity in the total filtrate $(100 \mu l)$ and the nonvolatile fraction $(200 \mu \mathrm{l}$, after the evaporation at $60^{\circ} \mathrm{C}$ ) of the filtrate. To measure ${ }^{3} \mathrm{H}$ activity in the macromolecular fraction, $550 \mu \mathrm{l}$ of $10 \%$ cold trichloroacetic acid (TCA) solution was added to $500 \mu \mathrm{l}$ of the filtrate with $50 \mu \mathrm{l}$ of carrier solution (1 $\mathrm{mg}$ $\mathrm{ml}^{-1}$ each of DNA, RNA and bovine serum albumin). After incubation for $10 \mathrm{~min}$ on ice, precipitates were collected on Millipore HA filters (pore size $0.45 \mu \mathrm{m}$ ), and the ${ }^{3} \mathrm{H}$-activity on the filters was measured with a liquid scintillation counter. Quenching was corrected by using channel ratio method.

We also measured the ${ }^{3} \mathrm{H}$-activity in the chloroform soluble fraction of the filtrate. The extraction was carried out according to Findlay et al. (1989). Briefly, $500 \mu$ of filtrate was mixed with $14.3 \mathrm{ml}$ of a lipid extraction mixture [chloroform:methanol:phosphate buffer $(50 \mathrm{mM}, \mathrm{pH} \mathrm{7.4)}=1: 2: 0.8)$ in a screw-capped tube. After vortexing, the tube was allowed to stand for 2 h. To separate aqueous and chloroform phases, chloroform and buffer ( $3.57 \mathrm{ml}$ each) were added to the tube. Then the tube was vortexed and allowed to stand overnight. The chloroform phase was transferred to a $20 \mathrm{ml}$ scintillation vial and evaporated under a flow of argon. The dried material was redissolved with $100 \mu \mathrm{l}$ of chloroform and the radioactivity was measured with a liquid scintillation counter.

We used triplicate vials for both flagellate + bacteria culture and bacteria-alone control. Release rate of ${ }^{3} \mathrm{H}$ compounds was calculated by subtracting the release in bacteria-alone control from the release in flagellate + bacteria culture.

We measured acid phosphatase activity in the culture of flagellates grazing on bacteria (Vibrio splendidus) and in the bacteria-alone control. Acid phosphatase activity in the cell-free filtrate $(0.2 \mu \mathrm{m}$ filtrate $)$ of the culture was measured by the use of a fluorogenic substrate (Hoppe 1983). We added $300 \mu$ of an acetate buffer $(50 \mathrm{mM}, \mathrm{pH} \mathrm{4.9)}$ to $150 \mu \mathrm{l}$ of sample in a $7 \mathrm{ml}$ glass vial. The reaction was initiated by adding $4.5 \mu \mathrm{l}$ of substrate $15 \mathrm{mM}$ methylumbelliferyl-phosphate dissolved in methoxyethanol). After incubation for 1 to $6 \mathrm{~h}$ at $30^{\circ} \mathrm{C}$, the reaction was stopped by adding $5 \mathrm{ml}$ of borate buffer ( $300 \mathrm{mM}$, pH 10). Fluorescence was measured with a fluorometer (excitation $355 \mathrm{~nm}$, emission $400 \mathrm{~nm}$ ). After the correction for fluorescence in artificial seawater alone, the amount of phosphate released by the enzyme reaction was calculated with a standard 
curve obtained with methylumbelliferon. In this paper, enzyme activity is expressed in arbitrary units; one unit of enzyme hydrolyzes the substrate to release $1 \mu \mathrm{mol}$ of phosphate per hour under the condition described above.

To examine the relation between $\mathrm{pH}$ and phosphatase activity, we measured acid phosphatase activity in the filtrate flagellate + bacteria culture at different pH's. The assay condition was the same as described above except buffers of different pH's ( 3 to 8) were used for the reaction mixture. The buffers used were acetate (50 mM; pH 3.0 to 5.5$)$, citrate (50 mM; pH 5.5 to 6.0$)$, and Tris- $\mathrm{HCl}(50 \mathrm{mM}, \mathrm{pH} 7.2$ to 8.0$)$ buffers.

We examined the effect of proteases (pronase $E_{\text {, }}$ Sigma Type XIV) and polymyxin B (Sigma) on the activity of acid phosphatase released by flagellates. Pronase $\mathrm{E}$ and polymyxin $\mathrm{B}$ were dissolved in borate buffer $(\mathrm{pH} 7.2,0.03 \mathrm{M}$ borate buffer with $0.005 \mathrm{M}$ $\mathrm{CaCl}_{2}$ ) at a concentration of $2 \mathrm{mg} \mathrm{ml}^{-1}$. Degradation reaction was initiated by mixing $75 \mu]$ of sample $[0.2 \mu \mathrm{m}$ filtrate of flagellate + bacteria cultures (stationary growth phase)], $50 \mu \mathrm{l}$ of Pronase E solution and $50 \mu \mathrm{l}$ of polymyxin $\mathrm{B}$ solution. After incubation for 2 to $3 \mathrm{~h}$ at $30^{\circ} \mathrm{C}$, acid phosphatase activity was assayed as described above. Controls (pronase E-alone, polymyxin $\mathrm{B}$-alone, without pronase $\mathrm{E}$ or polymyxin $\mathrm{B}$ ) were prepared by adding borate buffer instead of pronase $E$, polymyxin $\mathrm{B}$, or neither. Blanks were prepared with artificial seawater instead of sample. We also examined the effect of pronase $E$ and polymyxin $B$ on acid phosphatase isolated from wheat germ (Sigma, Type I). Reaction conditions were the same as described above.

To examine the size of organic molecules released by flagellates, we measured acid phosphatase activity in the $0.2 \mu \mathrm{m}$ filtrate of flagellate + bacteria cultures (early stationary phase) before and after ultracentrifugation (Sorvall RC60 with TV-865 vertical rotor: $5^{\circ} \mathrm{C}$, $41000 \mathrm{rpm}$, average centrifugal force $=147000 \times \mathrm{g}$ ). After centrifugation, $150 \mu \mathrm{l}$ of supernatant was collected from the center of centrifuge tubes, and acid phosphatase activity was measured as described above. To minimize adsorption of macromolecules to centrifuge tube walls, tubes (polyalloer) were pretreated with bovine serum albumin solution $\left(500 \mu \mathrm{g} \mathrm{ml}^{-1}\right.$, overnight at $5^{\circ} \mathrm{C}$ ) and rinsed with artificial seawater before use. The control consisted of samples kept in a refrigerator $\left(5^{\circ} \mathrm{C}\right)$ for the same time as that required for centrifugation.

\section{RESULTS}

To examine the release of DOM by flagellates, we measured the release of dissolved ${ }^{3} \mathrm{H}$-compounds by flagellates grazing on ${ }^{3} \mathrm{H}$-bacteria. Assuming that the

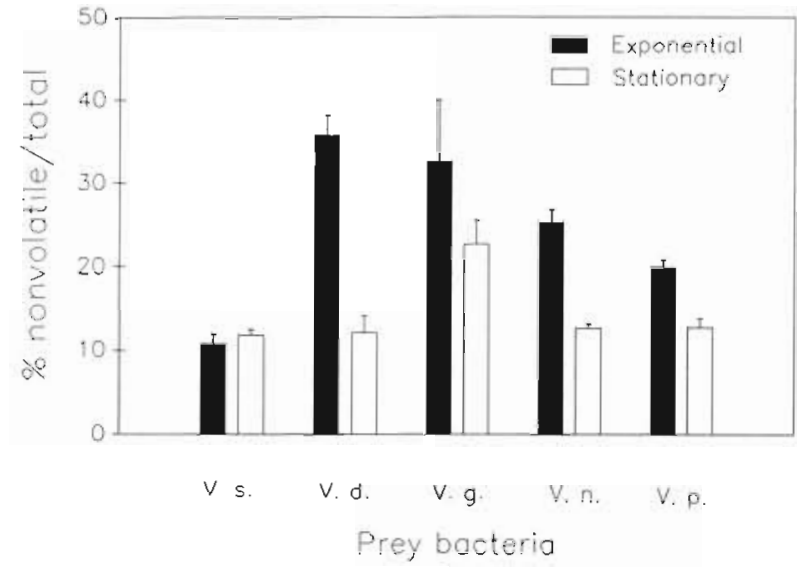

Fig. 1. Percentages of the ${ }^{3} \mathrm{H}$-DOM release to the total $\left({ }^{3} \mathrm{H}\right.$ DOM $+{ }^{3} \mathrm{H}_{2} \mathrm{O}$ ) release by flagellates grazing on ${ }^{3} \mathrm{H}$-bacterial prey (Vibrio spp.: V s., V. splendidus; V. d., V. damsela; V g., $V$. gazogenes; V. n., V. natriegens; V p., V. proteolyticus). Flagellates in the exponential phase (black columns) and the stationary phase (open columns) were used for the experiment. Errors are standard deviations $(\mathrm{n}=3)$

volatile fraction was dissolved ${ }^{3} \mathrm{H}_{2} \mathrm{O}$, we calculated that ${ }^{3} \mathrm{H}$-DOM release was 11 to $36 \%$ of total $\left({ }^{3} \mathrm{H}_{2} \mathrm{O}+{ }^{3} \mathrm{H}\right.$ DOM) release (Fig. 1). This contribution was significantly higher during the exponential phase than the stationary phase of flagellates (ANOVA, p $<0.001$ for Vibrio damsela, $V$. natriegens, and $V$. proteolyticus; $\mathrm{p}<0.1$ for $V$. gazogenes), except when $V$. splendidus was used as prey (Fig. 1). The percent contribution of DOM release varied depending on food type $(p<0.001)$.

We examined the distribution of ${ }^{3} \mathrm{H}$ in the macromolecular fraction (cold TCA precipitable fraction) and the lipid fraction (chloroform soluble fraction) of the DOM released by flagellates. Macromolecules were 5.5 to $56.9 \%$ of the released DOM, whereas lipids were 3.8 to $7.4 \%$ (Table 1 ). The contribution of macromolecules varied $(p<0.0005)$ depending on prey type and the growth stage of flagellates.

To compare the chemical composition of released DOM with that of prey bacteria, we calculated lipid: macromolecules ratios for ${ }^{3} \mathrm{H}$-DOM released by flagellates and those for prey ${ }^{3} \mathrm{H}$-bacteria. The ratios for the released DOM $(0.20$ to 0.92$)$ were higher than those for the prey bacteria ( 0.04 to 0.38 ) (Table 2$)$. The average ratio for the released DOM $(0.60 \pm 0.31)$ was significantly higher than that for the prey bacteria $(0.13 \pm$ $0.17)(p<0.05)$. These results suggest that the chemical composition of dissolved macromolecules released by the flagellates was different from that of bacterial prey; the released macromolecules were enriched with lipids.

The activity of acid phosphatase in the cell-free filtrate of flagellates + bacteria cultures increased with 
Table 1. Release of dissolved $\left(<0.2 \mu \mathrm{m}\right.$ ) ${ }^{3} \mathrm{H}$ as total macromolecules (cold TCA precipitable) and lipids (chloroform soluble). The release is expressed as a percentage ( $\pm \mathrm{SD}_{\mathrm{i}} \mathrm{n}=3$ ) of the total ${ }^{3} \mathrm{H}$-DOM (nonvolatile fraction) release. Vibrio spp. were used as bacterial prey

\begin{tabular}{|c|c|c|c|c|}
\hline \multirow[t]{2}{*}{ Prey type } & \multicolumn{2}{|c|}{ Cold TCA precipitable } & \multicolumn{2}{|c|}{ Chloroform soluble } \\
\hline & Exponential & Stationary & Exponential & Stationary \\
\hline V. splendidus & $26.4 \pm 7.1$ & $34.0 \pm 5.1$ & nd & nd \\
\hline V. damsela & $11.3 \pm 1.3$ & $5.5 \pm 3.0$ & $6.1 \pm 1.3$ & nd \\
\hline V. gazogenes & $10.0 \pm 5.0$ & $13.7 \pm 6.1$ & $7.4 \pm 3.2$ & $4.7 \pm 0.6$ \\
\hline$V$. natriegens & $28.1 \pm 1.5$ & $56.9 \pm 8.5$ & $5.5 \pm 0.5$ & $4.0 \pm 1.6$ \\
\hline$V$ proteolyticus & $7.2 \pm 1.3$ & nd & $6.6 \pm 0.5$ & $3.8 \pm 4.1$ \\
\hline
\end{tabular}

the increase of flagellate abundance (Fig. 2). In contrast, we did not detect acid phosphatase activity in bacteria-alone controls. These results indicated that the flagellates released acid phosphatase. The released phosphatase has an optimum $\mathrm{pH}$ of 4.9 and has no activity at the culture media $\mathrm{pH}$ of 7.5 (Fig. 3).

To examine the chemical nature of acid phosphatase released by flagellates, we added proteases to filtrates of flagellate + bacteria cultures and measured acid phosphatase activity over time. The activity did not change with the addition of proteases (Fig. 4A), indicating that the acid phosphatase released by the flagellate was resistant to protease degradation. In contrast, acid phosphatase purified from wheat germ was easily degraded by proteases and lost activity over time (Fig. 4C).

To investigate why acid phosphatase released by the flagellate was not degraded by proteases, we examined the effect of polymyxin $B$ on protease degradation of acid phosphatase. Results of the polymyxin experiment showed that polymyxin $B$ made the acid phosphatase susceptible to proteolytic attack (Fig. 4B). After $3 h, \%$ enzyme activity with protease was significantly lower than without protease $(p<0.05)$ in the presence of polymyxin. Addition of polymyxin B somewhat depressed degradation of wheat germ acid phosphatase (control) by proteases (Fig. 4D) probably

Table 2. Ratio of ${ }^{3} \mathrm{H}$ compounds in lipids vs total macromolecules in bacterial prey (Vibrio spp.) and the ${ }^{3} \mathrm{H}$-DOM released by flagellates growing exponentially

\begin{tabular}{|lcc|}
\hline Prey type & $\begin{array}{c}\text { Lipid : macromolecular ratios of: } \\
\text { Whole } \\
\text { bacteria }\end{array}$ & $\begin{array}{c}\text { Released } \\
\text { DOM }\end{array}$ \\
\hline V. damsela & 0.38 & 0.54 \\
V. gazogenes & 0.04 & 0.74 \\
$V$. natriegens & 0.04 & 0.20 \\
$V$. proteolyticus & 0.05 & 0.92 \\
Avg. $\pm \mathrm{SD}$ & $0.13 \pm 0.17$ & $0.60 \pm 0.31$ \\
\hline
\end{tabular}
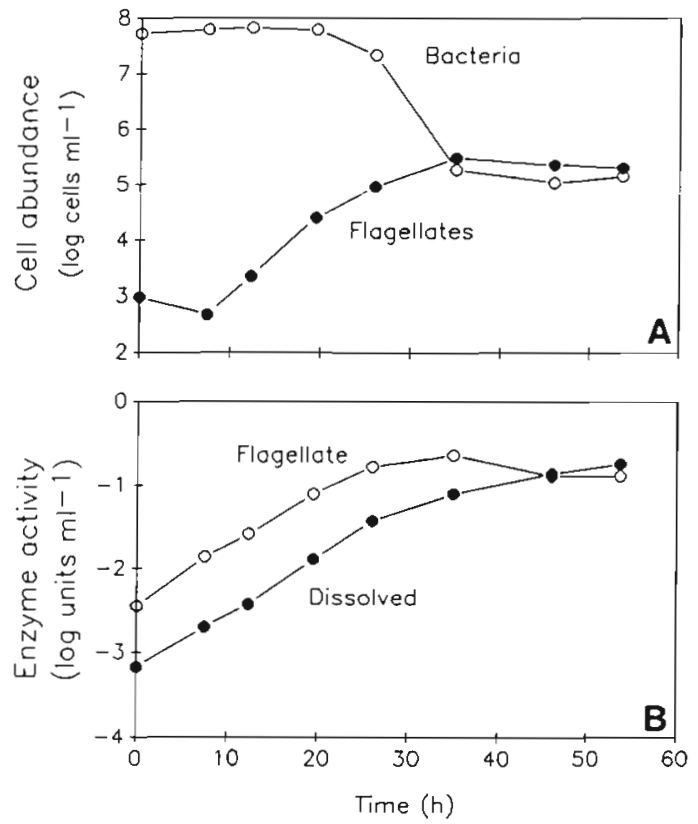

Fig. 2. (A) Changes of the abundance of flagellates and bacteria in a batch culture. (B) Acid phosphatase activities (arbitrary unit) in the particulate (flagellate) and dissolved $(<0.2 \mu \mathrm{m})$ fractions of the flagellate + bacteria culture

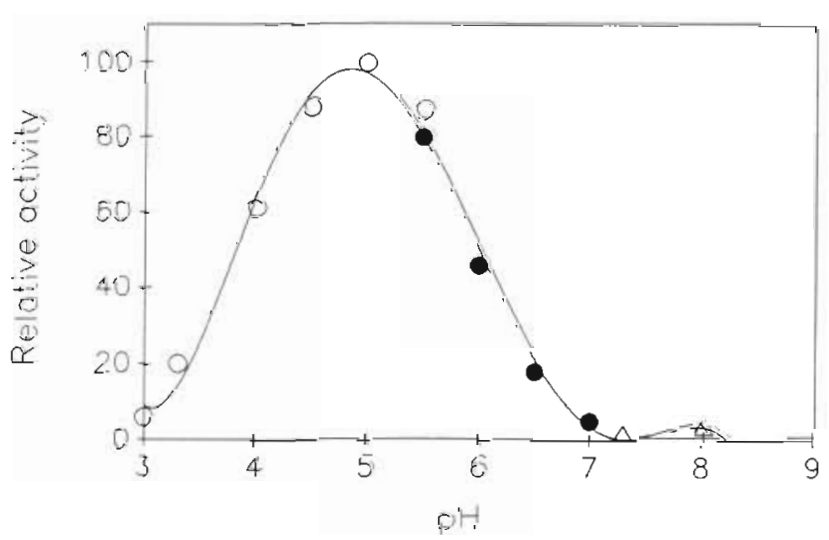

Fig. 3. pH-activity relationship of phosphatase in dissolved $(<0.2 \mu \mathrm{m})$ fraction of the flagellate + bacteria culture. Acetate $(0 ; 50 \mathrm{mM}, \mathrm{pH} 3.0$ to 5.5$)$, citrate $(50 \mathrm{mM}, \mathrm{pH} 5.5$ to 6.0$)$, and Tris ( $f ; 50 \mathrm{mM}, \mathrm{pH} 7.2$ to 8.0 ) buffers were used 
Flagellate Acid Phosphatose

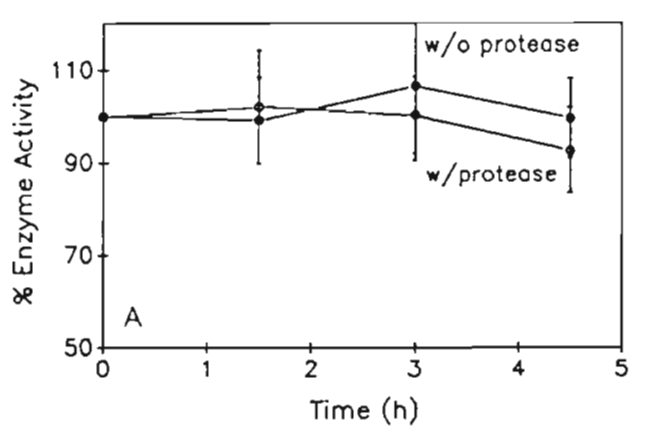

$w /$ polymyxin $B$

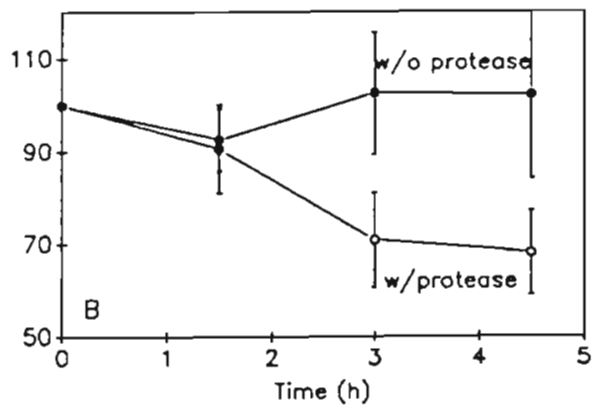

Wheat Germ Acid Phosphatase

Fig. 4. Effects of proteases (Pronase E) and polymyxin $\mathrm{B}$ on the activity of the acid phosphatase released by flagellates $(A, B)$ and that purified from wheat germ (C, D). Data are presented as the percentage of activities relative to the values at time zero $(100 \%)$. Error bars are standard deviations ( $\mathrm{n}=3$ )
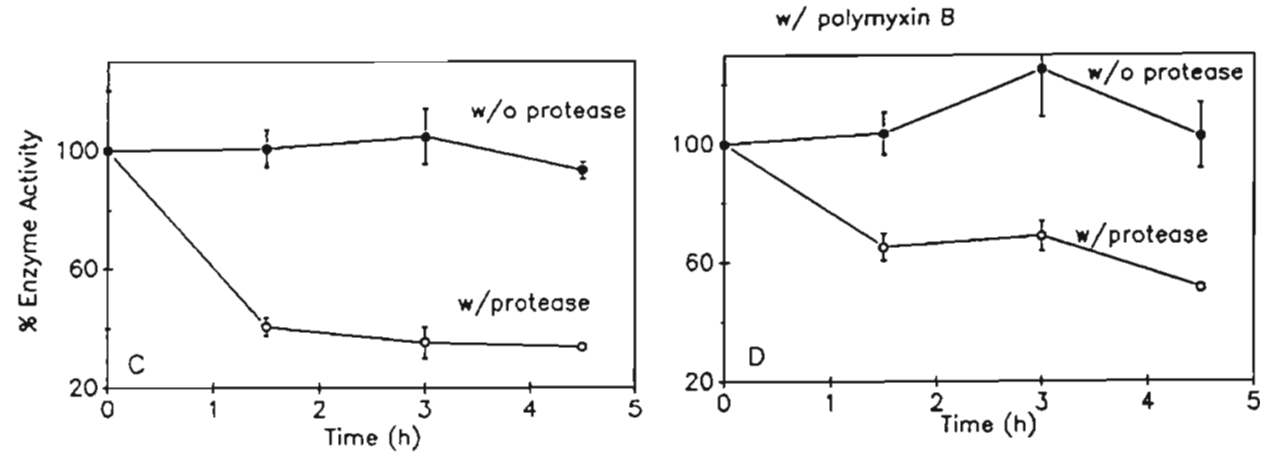

because of competitive inhibition (note that polymyxin $B$ is an oligopeptide).

To test whether the phosphatase released by flagellates forms an organic complex, we examined sedimentation of the phosphatase during ultracentrifugation $(147000 \times g)$. Phosphatase activity in the supernatant disappeared between 1 and 3 h (Fig. 5). In contrast, phosphatase activity in samples kept in the refrigerator (control) did not change. These results suggest that the decrease of the phosphatase activities in the ultracentrifuged samples was due to sedimentation, not adsorption to centrifuge tube walls or some unknown inactivation.

\section{DISCUSSION}

Previous work has shown that protozoan grazers are important in nutrient mineralization (Goldman et al. 1985) and biomass production (Sherr et al. 1986) in aquatic ecosystems. It is only recently that the ecological importance of the release of DOM by protozoa has become recognized (Nagata \& Kirchman 1991, 1992). Recent studies have found that bacterivorous protozoa release DOM including dissolved free and combined amino acids (Nagata \& Kirchman 1991), dissolved organic carbon (Taylor et al. 1985), and colloidal parti-

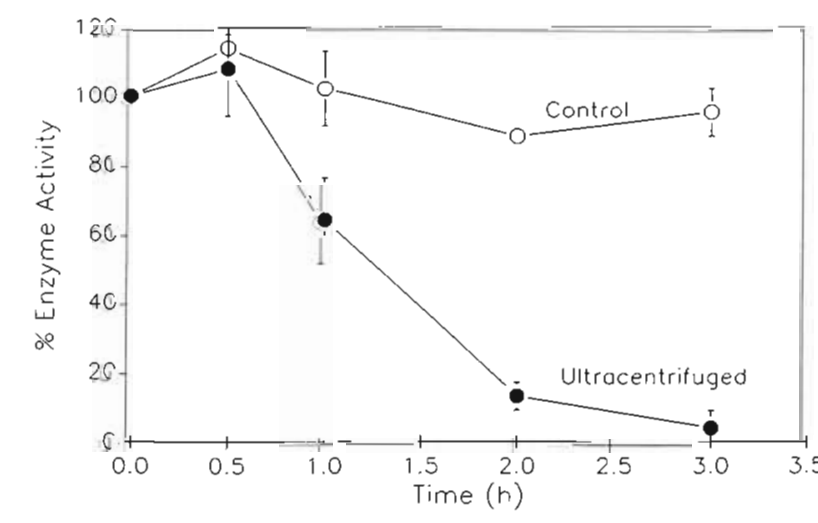

Fig. 5. Sedimentation of acid phosphatase released by flagellates. Phosphatase activities were measured in the supernatant after ultracentrifugation $\left(147000 \times \mathrm{g}, 5^{\circ} \mathrm{C}\right)$ for up to $3 \mathrm{~h}$. The control consisted of samples kept in a refrigerator $\left(5^{\circ} \mathrm{C}\right)$ for the same time as required for centrifugation. Data are presented as the percentage of activities relative to the values at time zero $(100 \%)$. Errors are standard deviations $(n=3)$

cles (Koike et al. 1990). Results of this study confirm and add to these findings. We found that flagellates grazing on ${ }^{3} \mathrm{H}$-labeled bacteria can release substantial amounts of ${ }^{3} \mathrm{H}$-DOM (Fig. 1). It should be noted that our estimate of DOM release was conservative because prey bacteria would degrade a portion of the ${ }^{3} \mathrm{H}-\mathrm{DOM}$ released by flagellates. Labile organic materials such 
as DFAA are degraded by bacteria, which may lead to underestimation of DOM release (Nagata \& Kirchman 1991, 1992).

The contribution of ${ }^{3} \mathrm{H}$-DOM to the total release of ${ }^{3} \mathrm{H}$ varied depending on prey type and the growth stage of flagellates (Fig. 1). Differences in composition of cell components of the prey probably explains this variation. Higher release of DOM during the exponential than stationary phase of the flagellate is consistent with results of Nagata \& Kirchman (1991). Flagellates probably release more DOM when ingestion is high because of lower assimilation (Jumars et al. 1989).

Our results also suggested that flagellates release dissolved macromolecules (cold TCA precipitable compounds) which contain large amounts of lipids (chloroform soluble compounds) (Table 1). Few studies have investigated the release of macromolecules by heterotrophic flagellates. Nagata \& Kirchman (1991) found that Paraphysomonas imperforata grazing on bacteria release dissolved combined amino acids However, they did not measure the size of these compounds. Koike et al. (1990) found that bacterivorous marine flagellates release submicron organic particles. Koike et al. proposed that flagellates are an important source of submicron organic colloids which are abundant in seawater. Because submicron particles can pass through $0.2 \mu \mathrm{m}$ membranes (I. Koike pers. comm.) these particles may be included in the macromolecular DOM that we measured. However, it is unclear at present whether the macromolecular DOM measured in our experiment exactly corresponds to the submicron particles measured by Koike et al.

We found that Paraphysomonas imperforata releases acid phosphatase (Fig. 2). Although previous studies have also found that flagellates release acid phosphatase (Aaronson 1971, Dubowsky 1974), mechanisms of the release and ecological importance are poorly understood. It is unlikely that $P$. imperforata releases acid phosphatase to utilize dissolved organic phosphorus because the pH-activity relation (Fig. 3) indicates that the released enzyme does not function at the $\mathrm{pH}$ of the flagellate culture $(\mathrm{pH} 7.5)$ and normal seawater. Several investigators have reported that food vacuoles of protozoa contain acid phosphatase (e.g. Cole \& Wynne 1974). Dubowsky (1974) observed with electron microscopy that phagotrophic flagellates Ochromonas malhamensis, fed on latex beads, release acid phosphatase (visualized by Gomori staining) when undigestible latex beads are egested. Flagellates probably release a portion of their digestive enzymes when the contents of food vacuoles are egested.

An interesting finding of this study was that acid phosphatase released by flagellates was degraded by proteases only after treatment with polymyxin B. Polymyxin $B$ is known to disrupt outer membranes of Gram- negative bacteria, leading to an increase in membrane permeability (Storm et al. 1977, Vaara \& Vaara 1983). Our interpretation of this result is that flagellate digestive enzymes were coated and thus protected by bacterial membranes which were partially degraded in food vacuoles of flagellates and released during egestion. A membrane coating may protect the phosphatase from proteases because large molecules cannot pass through membranes, although the fluorogenic substrate $(\mathrm{MW}=300$ ) of the phosphatase can penetrate membranes. Polymyxin $\mathrm{B}$ destroys this membrane barrier, making the phosphatase susceptible to protease attacks. In support of this hypothesis, we found that dissolved macromolecules released by the flagellates were rich in lipids (Table 2).

Results of the ultracentrifugation experiment (Fig. 5) also support our hypothesis. From the clearing factor $(K$ $=25.5)$, sedimentation time $(t=1$ to $3 \mathrm{~h})$, and a correction for the standard condition (i.e. in water at $20^{\circ} \mathrm{C}$ ) (Martin \& Ames 1961), we calculated that the sedimentation coefficient of the phosphatase was 15 to $42 \mathrm{~S}$. These high values suggest that the phosphatase released by flagellates is large and that the phosphatase forms an organic complex with membranes. It should be noted that this calculation was based on the assumption that the density of the enzyme was $1.379 \mathrm{~g}$ $\mathrm{cm}^{-3}$ (average density for proteins; Martin \& Ames 1961). If the phosphatase is coated by phospholipids, as we suggested above, the density should be lower because the density of phospholipid bilayer $(1.014 \mathrm{~g}$ $\mathrm{cm}^{-3}$; New 1990) is lower than that of proteins. With lower density, the sedimentation coefficients would be even higher (Martin \& Ames 1961). The important point is that the sedimentation coefficient could be underestimated, and our estimate of the size of the complex (15 to 42 S) may be too low.

It has been observed by electron microscopy that, at the later stage of digestion, food vacuoles of Paraphysomonas imperforata contain many membranous vesicular fragments which are 20 to $100 \mathrm{~nm}$ in size (G. B Chapman pers. comm.). Cole \& Wynne (1974) also observed membrane fragments in food vacuoles of Ochromonas danica grazing on cyanobacteria. These observations suggest that flagellates differentially degrade bacterial cell components, and that membranes are digested to a lesser extent (or at slower rates) than other components.

Phospholipids spontaneously form micelles (lipid aggregates with ordered structure) at or above the critical micelle concentrations (New 1990). When one bacterium is partially digested in a food vacuole and its phospholipids disperse in the vacuole, we estimate that the concentration of the phospholipids in the vacuole is $2 \mathrm{~g} \mathrm{l}^{-1}$ For this estimate we assume a lipid content per bacterial cell of $26 \times 10^{-15} \mathrm{~g}$ (Ingraham et al. 1983) and 
a food vacuole volume of $14 \mu^{3}$. Since the critical micelle concentration of phospholipids is $10^{-7}$ to $10^{-6} \mathrm{~g}$ $1^{-1}$ (Gennis 1989), this calculation suggests that bacterial phospholipids should spontaneously form micelles in the food vacuoles of flagellates. Electron microscope observations (Cole \& Wynne 1974, G. B. Chapman pers. comm.) support this hypothesis; loops of membrane fragments were seen in thin sections of food vacuoles, suggesting that liposome-like particles are formed. Acid phosphatase, other digestive enzymes of flagellates, and bacterial proteins in food vacuoles could be trapped within micelles (liposomes) of partially degraded bacterial membranes.

Undigested prey materials including liposome-like particles in food vacuoles are probably released to the surrounding water during egestion. Cole \& Wynne (1974) suggested that the secondary endosomes (food vacuoles at the later stage of digestion) of Ochromonas danica fuse with cytoplasmic membranes of the flagellate and exocytosis occurs along this interface. However, the actual mechanisms of exocytosis are unclear.

The release of protein-membrane complexes by flagellates, if proved to be general, has important implications for material cycling in the oceans. First, it may help explain transformation of labile DOM to recalcitrant DOM which is believed to be the major constituent of oceanic DOM (turnover rates of oceanic DOC greater than 1000 yr; Williams \& Druffel 1987). Previous studies have demonstrated that biopolymers such as proteins are rapidly degraded by bacteria; turnover rates are on the order of hours, similar to dissolved free amino acids (Hollibaugh \& Azam 1983, Coffin 1989). Thus, it seems unlikely that labile proteins can persist in natural waters without chemical modification. Coating of proteins by membranes, which we propose to occur associated with flagellate grazing and egestion, may protect labile proteins from protease degradation. Moreover, membrane coating may keep the concentrations of proteins high inside the vesicles, providing conditions that facilitate chemical transformations of labile proteins to recalcitrant forms. If so, the liposomelike particles may work as a 'reaction chamber' in which chemical reactions incapable of occuring in diluted conditions could proceed rapidly.

The membrane-protein complex (presumably a liposome-like structure) also may be important as a carrier of biologically important materials. There are many biochemical and pharmacological applications of liposomes as carriers of water soluble and insoluble compounds to animal, plant and bacterial cells (Gregoriadis 1984). Analogously, we speculate that liposome-like vesicles could be incorporated by algae and bacteria through fusing of lipids, and play important roles in the transfer of nutrients such as nitrogen, phosphorus, and iron within aquatic systems.
Acknowledgements. We thank Jessica Hufford and Anne Woomer for technical help and Isao Koike for comments. This research was supported by ONR contract N00014-90-J-1973.

\section{LITERATURE CITED}

Aaronson, S. (1971). The synthesis of extracellular macromolecules and membranes by a population of the phytoflagellate Ochromonas danica. Limnol. Oceanogr. 16: 1-9

Coffin, R. B. (1989). Bacterial uptake of dissolved free and combined amino acids in estuarine waters. Limnol. Oceanogr. 34: 532-542

Cole, G. T., Wynne, M. J. (1974). Endocytosis of Microcystis aeruginosa by Ochromonas danica. J. Phycol. 10: 397-410

Dubowsky, N. (1974). Selectivity of ingestion and digestion in the chrysomonad flagellate Ochromonas malhamensis. J. Protozool. 21: 295-298

Eppley, R. W., Holmes, R. W., Strickland, J. D. H. (1967) Sinking rates of marine phytoplankton measured with a fluorometer. J. exp. mar. Biol. Ecol. 1: 191-208

Findlay, R. H., King, G. M., Watling, L. (1989). Efficacy of phospholipid analysis in determining microbial biomass in sediments. Appl. environ. Microbiol. 55: 2888-2893

Gennis, R. B. (1989). Biomembranes: molecular structure and function. (Series Ed.: Cantor, C. R., Springer Advanced Texts in Chemistry.) Springer-Verlag. New York

Goldman, J. C., Caron, D. A., Andersen, O. K., Dennett, M. R. (1985). Nutrient cycling in a microflagellate food chain: 1 . Nitrogen dynamics. Mar. Ecol. Prog. Ser. 24: 231-242

Gregoriadis, G. (ed.) (1984). Liposome technology, Vols. 1, 2, and 3. CRC Press, Boca Raton, Florida

Hollibaugh, J. T., Azam, F. (1983). Microbial degradation of dissolved proteins in seawater Limnol. Oceanogr. 28: $1104-1116$

Hoppe, H.-G. (1983). Significance of exoenzymatic activities in the ecology of brackish water: measurements by means of methylumbelliferyl-substrates. Mar. Ecol. Prog. Ser. 11 : 299-308

Ingraham, J. L., Maalee, O., Neidhardt, F. C. (1983). Growth of the bacterial cell. Sinauer Associates, Inc., Sunderland, Massachusetts

Jackson, G. A., Williams, P. M. (1985). Importance of dissolved organic nitrogen and phosphorus to biological nutrient cycling. Deep Sea Res. 32: 223-235

Jumars, P. A., Penry, D. L., Baross, J. A., Perry, M. J., Frost, B. W. (1989). Closing the microbial loop: dissolved carbon pathway to heterotrophic bacteria from incomplete inges. tion, digestion and absorption in animals. Deep Sea Res. 36: $483-495$

Kirchman, D. L., Suzuki, Y., Garside, C., Ducklow, H. W. (1991). High turnover rates of dissolved organic carbon during a spring phytoplankton bloom. Nature, Lond. 352: 612-614

Koike, I., Hara, S., Terauchi, K., Kogure, K. (1990). Role of submicrometer particles in the ocean. Nature, Lond. 345 242-244

Longhurst, A. R., Koike, I., Li, W K. W., Rodriguez, J., Dickie, P., Kepay, P., Partensky, F., Bautista, B., Ruiz, J., Wells, M., Bird, D. F. (1992). Sub-micron particles in northwest Atlantic shelf water. Deep Sea Res. 39: 1-7

Martin, R. G., Ames, B. N. (1961). A method for determining the sedimentation behavior of enzymes: application to protein mixtures. J. biol. Chem. 236: 1372-1379

Nagata, T., Kirchman, D. L. (1990). Filtration-induced release of dissolved free amino acids: application to cultures of marine protozoa. Mar Ecol. Prog. Ser. 68: 1-5 
Nagata, T., Kirchman, D. L. (1991). Release of dissolved free and combined amino acids by bacterivorous marine flagellates. Limnol. Oceanogr. 36: 433-443

Nagata, T., Kirchman, D. L. (1992). Release of dissolved organic matter by heterotrophic protozoa: implications for microbial food webs. Arch. Hydrobiol. Beih. Ergebn. Limnol. 35: 99-109

New, R. R. C. (ed.) (1990). Liposomes: a practical approach IRL Press, Oxford

Ogura, N. (1974). Molecular weight fractionation of dissolved organic matter in coastal seawater by ultrafiltration. Mar. Biol. 24: 305-312

Sharp, J. H. (1973). Size classes of organic carbon in seawater. Limnol. Oceanogr, 18: $441-447$

Sherr, E. B., Sherr B. F., Paffenhöfer, G.-A. (1986). Phagotrophic protozoa as food for metazoans: a 'missing' trophic link in marine pelagic food webs? Mar microb. Food Webs 1: 61-80

Storm, D. R., Rosenthal, K. S., Swanson, P. E. (1977). Polymyxin and related peptide antibiotics. Ann. Rev. Biochem. 46: $723-763$

This article was presented by S. Y. Newell, Sapelo Island, Georgia, USA
Taylor, G. T., Iturriaga, R., Sullivan, C. W (1985). Interactions of bacterivorous grazers and heterotrophic bacteria with dissolved organic matter. Mar. Ecol. Prog. Ser 23: 129-141

Toggweiler, J. R. (1989). Is the downward dissolved organic matter (DOM) flux important in carbon transport? In: Berger, W. H., Smetacek, V. S., Wefer, G. (eds.) Productivity of the ocean: present and past. John Wiley \& Sons, Chichester, p. 65-83

Vaara, M., Vaara, T. (1983). Sensitization of Gram-negative bacteria to antibiotics and complement by a nontoxic oligopeptide. Nature, Lond. 303: 526-528

Wells, M. L., Goldberg, E. D. (1991). Occurrence of small colloids in sea water. Nature, Lond. 353: 342-344

Williams, P. M., Druffel, E. R. M. (1987). Radiocarbon in dissolved organic matter in the central North Pacific Ocean. Nature, Lond. 330: 246-248

Williams, P. M., Druffel, E. R. M. (1988). Dissolved organic matter in the ocean: comments on a controversy. Oceanogr Mag. 1: 14-17

Manuscript first received: February 5, 1992

Revised version accepted: April 22, 1992 